TELAGA BAHASA

Volume 5

No. 2 Desember 2017

Halaman 243-260

\title{
RELASI KUASA TOKOH LAKI-LAKI DAN PEREMPUAN DALAM NOVEL GARIS PEREMPUAN KARYA SANIE B. KUNCORO
}

\section{(Power Relation Between Male and Female in Garis Perempuan by Sanie B. Kuncoro)}

\author{
Ery Agus Kurnianto \\ Balai Bahasa Jawa Tengah \\ Jalan Elang Raya Nomor 1, Mangunharjo \\ Tembalang, Semarang \\ Pos-el: eryagus75@gmail.com
}

\begin{abstract}
Abstrak
Persoalan kekuasaan antara laki-laki dengan perempuan dalam konstruksi budaya patriarki menjadi hal yang sangat menarik. Perempuan menjadi pihak yang terepresi oleh kekuasaan laki-laki karena konstruksi budaya yang dibentuk oleh laki-laki. Salah satu media yang dapat digunakan oleh perempuan untuk melawan konstruksi tersebut adalah karya sastra. Objek penelitian ini adalah novel Garis Peremuan karya Sanie B. Kuncoro dalam bingkai strukturalisme, yaitu mengidentifikasi prilaku, pola pikir, dan mitos seputar perempuan yang terdapat dalam novel tersebut. Teori representasi dan gender digunakan untuk mengidentifikasi representasi tokoh perempuan. Metode yang digunakan dalam penelitian ini adalah metode deskriptif analitis dengan menggunakan pendekatan objektif. Pendekatan objektif dilakukan dengan cara melakukan analisis unsur instriksik berdasarkan pada fakta-fakta empiris yang terdapat dalam karya. Hasil penelitian menunjukkan bahwa representasi yang muncul adalah representasi perempuan sebagai colonized dan sebagai perempuan feminist.
\end{abstract}

Kata Kunci: relasi kuasa, representasi, tokoh laki-laki, tokoh perempuaan

\footnotetext{
Abstract

The issue of power between men and women in the construction of patriarchal culture becomes very interesting. Women become parties repressed by the power of men because of the cultural construction formed by men. One of the media that can be used by women to resist construction is literary work. The object of this research is a novel entitled Garis Perempuan by Sanie B. Kuncoro. Within the concept of structuralism, the writer aims to identify the behavior, mindset, and myths concerning women
} 
that are represented in the novel. The writer uses gender and representation theory to identify the representation of women. The method used in this paper is descriptive-analytic with an objective approach. The objective approach by analyzing intrinsic elements based on the empirical facts contained in the work. The result shows that women are represented as colonized and feminist.

Keywords: power relations, the representation of women, male characters, female character

\section{PENDAHULUAN}

Karya sastra adalah hasil tiruan dunia nyata dan dunia imaji. Dunia imaji dalam karya sastra membentuk sebuah dunia yang peristiwa dan pelakunya sama dengan peristiwa dan pelaku di dunia nyata. Abrams (dalam Faruk, 1994:4), menyatakan bahwa "art is like a miror". Hal senada juga diungkapkan oleh De Bonald (dalamWellek \& Warren, 1995: 110) menyatakan bahwa 'literature is an expression of society. Bedasarkan pada pernyataan kedua ahli tersebut dapat dinyatakan bahwa karya sastra adalah cerminan dunia realita. Namun, dunia yang ada di dalam karya sastra tidak seratus persen sama dengan duni nyata. Hal tersebut disebabkan sang pencipta dunia sastra, pengarang, dengan daya imajinasi dan kreasinya mengolah kembali dunia nyata menjadi sebuah konstruksi dunia sastra sesuai dengan apa yang diinginkannya. Sarana literer yang digunakan oleh pengarang dalam dunia ciptannya merupakan salah satu hasil kreasi dan imajinasi pengarang. Oleh karena itu, dunia sastra memiliki kekuatan di dunia fiktif dan imajinatif. Berkaitan dengan hal tersebut, Al Ali (1994:10) menyatakan bahwa

Karya sastra merefleksikan dan memisrefleksikan kehidupan; karya sastra mengacu kepada kehidupan. Karya sastra menyajikan memisrefleksikan yang memperbesar atau menghilangkan beberapa aspek dari kenyataan, memelintir aspek tertentu atau meninggalkannya sama sekali.

Berdasarkan hal tersebut dapat dinyatakan bahwa menulis karya sastra berarti menafsirkan dunia berdasarkan alternatif subjektif pengarang. Pengarang tidak hanya sekadar merefleksikan dunia nyata dalam karyanya. Hal itulah yang membedakan tulisan sastra dengan tulisan berita.

Karya sastra memiliki fungsi atau manfat bagi pengarang maupun pembacanya. Karya sastra, yang merupakan refleksi 
ideologi pengarangnya, mampu memporakporandakan tatanan sosial yang terbentuk dalam suatu komunitas sosial. Karya sastra dapat digunakan untuk mendekonstruksi hubungan yang timpang antara laki-laki dan perempuan. Atau sebaliknya, karya sastra juga dapat digunakan untuk melanggengkan hubungan yang timpang tersebut.

Karya sastra selalu menghadirkan dinamika sosial yang terjadi dalam kehidupan masyarakat. Karya sastra juga menghadiran resistensi terhadap fenomena sosial yang ada di lingkungan sekitar pengarangnya. Karya sastra menjadi media pengarangnya untuk menyampaikan ide-ide yang tidak dapat disampakan secara langsung. Misalnya, ide tentang penyetaraan peran sosial antara laki-laki dengan perempuan. Menurut Figes (1986:15) perempuan itu dibentuk laki-laki. Perempuan dan anak-anak perempuan lebih terikat dengan anturan dan norma-norma yang berlaku di dalam masyarakat dibandingkan dengan laki-laki. Konstruksi budaya yang berlaku dalam masyarakat menganggap bahwa laki-lakilah yang memainkan peranan penting dalam keberlanjutan kehidupan sehingga selayaknyalah laki-laki yang memiliki kuasa atas segala hal termasuk kehidupan perempuan. Dalam proses persetubuhan laki-laki itu berperan sebagai pihak yang membuahi dan perempuan sebagai pihak yang dibuahi yang bersifat pasif menunggu untuk dibuahi. Proses membuahi dan dibuahi melahirkan konsep bahwa yang membuahi memiliki dominasi dan kekuasaan atas yang dibuahi.

Sanie B. Kuncoro melalui karyanya yang berjudul Garis Perempuan ingin menyampaikan ide-idenya sebagai wakil perempuan. Melalui karyanya itu, Sanie B. Kuncoro melakukan resistensi terhadap tatanan sosial yang terbentuk, bertahan bahkan berkembang karena diwariskan secara turun temurun. Relasi kuasa yang terjadi antara perempuan dengan laki-laki dijungkirbalikan dalam dunia imaji ciptaannya. Berdasarkan hal tersebut masalah yang akan dibahas dalam penelitian ini adalah bagaimana bentuk hubungan kekuasaan antara tokoh laki-laki dengan tokoh perempuan. Tujuan penelitian ini mendeskripsikan hubungan kekuasaan antara tokoh laki-laki dengan tokoh perempuan.

Pada dasarnya alasan mengapa peneliti mengambil novel Garis Perempuan sebagai sumber data dalam penelitian ini karena Garis Perempuan menampilkan suasana perlawanan untuk menyejajarkan kedudukan hubungan kekuasaan antara lakilaki dengan perempuan. Novel itu memang sangat menarik karena Sanie B. Kuncoro mengungkapkan kekuatan 
keperempuanannya melalui empat tokoh perempuan yang diciptakan dalam karyanya.

\section{TEORI}

Untuk mendapatkan gambaran secara nyata tentang relasi kuasa yang terdapat dalam novel Garis Perempuan, penulis melakukan analisis terhadap unsur instriksik karya sastra. Unsur intrinsik yang dianalisis adalah alur dan sudut pandang. Dalam penelitian ini plot akan difokuskan pada hubungan kausalitas yang menyebabkan hadirnya kesadaran diri pada tokoh-tokoh perempuan (Ranting, Gendhing, Tawangsri, dan Zhang Mey) atas posisi yang dimilikinya terhadap tokoh laki-laki yang ada dalam novel GP sehingga memunculkan suatu konflik.

Foster (1970:93) mendefinisikan alur a narrative og events, the emphasis falling on causality (Alur merupakan peristiwaperistiwa cerita yang memiliki penekanan pada adanya hubungan sebab akibat). Dari pendapat tersebut dapat dinyatakan bahwa suatu peristiwa dimunculkan karena adanya sebab akibat atau kausalitas. Suatu peristiwa disebabkan oleh suatu hal dan mengakibatkan munculnya suatu hal. Dari jalinan hal-hal tersebut terbentuk sebuah peristiwan yang atau jalannya suatu peristwa.
Abrams (1981: 42) menyatakan bahwa sudut pandang adalah cara pandang yang dipakai oleh pengarang untuk menampilkan tokoh, tindakan, latar, dan berbagai peristiwa yang membentuk cerita dalam suatu karya fiksi. Senada dengan hal tersebut, Nurgiyantoro (2009:248) menyatakan bahwa sudut pandang pada hakikatnya merupakan strategi, teknik, dan siasat yang dengan sengaja dipilih oleh penulis cerita untuk menggambarkan atau menyajikan peristiwa-peristiwa yang terjadi di dalam karya fiksi dalam mengemukakan gagasan atau ide cerita.

Diskusi tentang kekuasaan merupakan satu topik menarik yang tidak pernah selesai dibahas. Hal tersebut disebabakan wacana kekuasaan merupakan isu yang selalu terbaharui. Berkaitan dengan itu, Michael (1996:146) menyatakan bahwa pembicaraan mengenai kekuasaan tetap penting terutama ketika umat manusia berkepentingan untuk terus menemukan cara bagaimana menyeimbangkan kekuasaan.

Membahas masalah kekuasaan, teori Foucault paling tepat digunakan sebagai 'pisau bedah' dalam penelitian ini. Sasaran kekuasaan menurut Foucault (Jones, 2003: 175) bisa siapa saja. Baik individu atau kelompok. Relasi kuasa beroperasi pada pemikiran (ideologi) hingga tubuh, yang akhirnya mempengaruhi perilaku. 
Foucault (dalam Sulistya dkk., 2011: 135) mendefiniskan relasi kuasa sebagai sesuatu yang membuat orang patuh. Relasi kuasa merupakan konsep hubungan kekuasaan yaitu praktik-praktik kekuasaan dari subyek pada obyek melalui berbagai media dan rupa. Kekuasaan yang dimaksudkan tidak didapat dari cara-cara yang represif, melainkan secara manipulatif dan hegemonik.

Lebih lanjut Foucault dalam Dicipline and Punish: The Birth of Prison (dikutip Sulistya dkk., 2011: 135) mengatakan bahwa terdapat lima cara suatu kekuasaan dapat beroperasi.

a. Kekuasaan tidak diambil, diperoleh, atau dibagikan. Kekuasaan berjalan dari berbagai titik, dalam hubungan yang tidak setara dan selalu bergerak.

b. Kekuasaan bersifat cair. Maksudnya kekuasaan adalah efek langsung dari pembagian, pembedaan,

ketidaksetaraan, dan

ketidakseimbangan.

c. Hubungan kekuasaan tidak berada dalam posisi suprastruktur. Kekuasaan datang dari bawah, artinya tidak ada oposisi biner antara yang mendominasi dan yang dominan. Hubungan semacam itu terbentuk dalam aparat produksi seperti dalam keluarga, kelompok, maupun institusi.

d. Hubungan kekuasaan bersifat intensional. Tidak ada kekuasaan tanpa serangkaian sasaran. Rasionalitas kekuasaan adalah taktik yang terselubung pada tingkat teratas.

e. Kekuasaan selalu mendapatkan tandingan kuasa lainnya dimanapun berada. Kekuasaan selalu melahirkan anti kekuasaan. Anti kekuasaan tersebut sebenarnya adalah untuk mengejawantahkan kekuasaan lainnya sebagai tandingan.

Novel Garis Perempuan karya Sanie B. Kuncoro yang diteliti dalam tulisan ini mengungkap permasalahan gender, khususnya sikap dan posisi laki-laki dan perempuan dalam suatu masyarakat yang melahirkan berbagai wacana tentang perempuan dan laki-laki yang dikonstruksi oleh masyarakat yang menganut sistem patriarki.

Gender dalam Kamus Besar Bahasa Indonesia diartikan sebagai 'jenis kelamin' (2008:439). Namun sebenarnya gender memiliki definisi yang lebih khusus-bukan hanya sekadar jenis kelamin. Tierney (1991:153) dalam Women's Studies Encyclopedia mengartikan gender sebagai "the distinction in roles, behaviors, and mental and emotional characteristics 
between females and males developed by a society". Definisi tersebut juga dianut oleh Fakih (1997:71-72) yang menyatakan bahwa gender adalah perbedaan perilaku antara laki-laki dan perempuan yang dikonstruksi secara sosial maupun kultural. Berdasarkan pendapat tersebut dapat diartikan bahwa gender adalah perbedaan antara laki-laki dan perempuan yang tidak hanya berdasarkan pada jenis kelaminnya saja, melainkan juga peranan yang dimiliki oleh laki-laki dan perempuan dalam kehidupan sosial yang dititikberatkan pada tindakan, peranan, dan fungsi masing-masing yang ditentukan dan dibentuk oleh kebiasaan masyarakat ia berada. Gender dapat juga diartikan sebagai suatu konsep yang dapat digunakan untuk mengidentifikasikan perbedaan antara laki-laki dan perempuan berdasarkan sosial budaya masyarakatnya.

\section{METODE}

Metode yang digunakan dalam tulisan ini adalah metode deskriptif. Metode tersebut cocok untuk dipakai karena tulisan ini melibatkan data untuk mendeskripsikan atau menggambarkan fenomena yang ada dalam data tersebut. Sementara itu untuk menganalisis novel Garis Perempuan yang terkait dengan permasalahan relasi kuasa dan isu gender, penulis akan menerapkan teori relasi kuasa dan teori gender. Berdasarkan teori tersebut akan diungkapkan strategi teks dalam mendobrak wacana tentang perempuan dalam masyarakat patriarki.

Data penelitian ini bersumber dari sumber data utama yang berupa novel Garis Perempuan. Sumber data pendukun yang berupa dokumen tertulis yang berupa sejumlah teks, baik yang membahas novel Garis Perempuan maupun tulisan lain yang dianggap berkaitan dengan penelitian ini.

\section{PEMBAHASAN}

Kekuasaan yang dimaksud dalam penelitian ini adalah sebuah relasi atau hubungan yang berkaitan dengan sejauh mana suatu jenis kelamin dalam mengontrol jenis kelamin lainnya untuk menentukan pilihannya. Dikotomi kekuasaan memunculkan pihak yang dikuasai dan pihak yang menguasai. Dalam relasi sosial, kedua pihak selalu berinteraksi. Proses interaksi memunculkan hegemoni kekuasaan. Pihak yang menguasai akan selalu mendominasi dibandingkan dengan pihak yang dikuasai. Biasanya pihak yang dikuasasi tidak memiliki akses kepada kekuasaan hegemoni. Pihak yang mendominasi dapat mengontrol dan membentuk pihak yang didominasi. Dalam hal ini akan terlihat relasi kuasa antara laki-laki dan perempuan. Dalam relasi sosial, kedua pihak selalu berinteraksi. Untuk dapat mengintepretasikan hubungan tersebut, 
langkah analisis anasir terhadap alur dan sudut pandang harus dilakukan.

Alur dan Sudut Pandang Novel Garis

\section{Perempuan}

Novel GP dibangun dengan struktur alur yang kompleks. Kompleks dalam artian setiap bagian cerita yang muncul dalam novel ini memunculkan konflik antara lakilaki dan perempuan. Konflik antara Ranting dengan Basudewo, Gendhing dengan Indragiri dan rentenir, Tawangsri dengan Jenggala, dan Zhang Mey dengan Tenggar. Alur dalm cerita $G P$ berpusat pada perempuan, yaitu berpusat pada Ranting, Gendhing, Tawangsri, dan Zhang Mey.

Cara berpikir dan sudut pandang dalam mengahadapi suatu persoalan antara tokoh perempuan dan tokoh laki-laki yang terdapat dalam novel GP menunjukkan adanya sebuah hubungan suatu sebab yang memunculkan suatu akibat. Hubungan tersebut saling memiliki hubungan dan terjalin membentuk suatu peristiwa yang terus mengalir sehingga sampailah pada suatu pemecahan konflik atau selesaian. Kesejajaran keempat alur utama yang ditampilkan oleh pengarang memiliki fungsi untuk mempertajam idiologi atau sudut pandang terhadap suatu persoalan yang diangkat oleh pengarang.
Sudut pandang yang digunakan oleh pengarang adalah sudut pandang orang ketiga maha tahu. Pengarang menjadi seorang narator yang posisinya berdiri di luar cerita. Dia menguasai semua tokoh yang ditampilkan dalam cerita. Dan dia juga mengetahui semua konflik dan solusi yang ditampilkan dalam cerita. Untuk mempertajam dan mempertegas ideologi tokoh utama, pengarang masuk ke dalam pergulatan batin dan pikiran tokoh-tokoh perempuan yang ada di dalam novel tersebut.

Hubungan Kekuasaan antara Tokoh Perempuan dan Laki-Laki

Hubungan kekuasaan yang terjadi antara tokoh laki-laki dan perempuan tidak disebutkan secara eksplisit oleh pengarangnya. Oleh karena itu, novel GP harus dibaca secara teliti dan cermat oleh pembacanya. Setelah pembacaan secara cermat dan teliti dilakukan, pembaca akan dapat mengintepretasikan hubungan antara tokoh Gending dengan Tokoh Basudewo, Hubungan antara Gendhing dengan Indragiri, Hubungan antara Tawangsri dengan Jenggala, dan Hubugan antara Zhang Mey dengan Tenggar.

\section{Hubungan Ranting dengan Basudewo.}

Telah disebutkan di bagian terdahulu bahwa hubungan kekuasaan antara tokoh 
laki-laki dan perempuan tidak disebutkan secara gamblang oleh pengarang novel GP. Namun demikian, secara implisit dapat ditarik suatu temuan bahwa hubungan antara Ranting dengan Basudewo adalah hubungan kekuasaan yang vertikal, bukan horisontal. Hal tersebut mengintepretasikan bahwa hubungan antara Ranting dan Basudewo adalah hubungan antara kekuasaan laki-laki dengan perempuan. Basudewo ingin menguasai tubuh dan kecantikan yang dimiliki oleh Ranting. Peluang untuk mendapatkan itu semua sangat terbuka lebar bagi Basudewo mengingat Posisi Basudewo yang sangat dibutuhkan oleh Ranting untuk membiayai biaya rumah sakit dan operasi tumor ibunya. Tercermin hubungan antara orang yang memiliki kekuasaan dengan orang yang dikuasai. Bentuk konstrusi patriarki yang menempatkan laki-laki sebagai pihak ordinat dan perempuan yang subordint. Hubungan Ranting dan Gending juga merepresentasi hegemoni kekuasaan. Pihak kuat akan selalu meraih kesuksesan untuk mencapai apa yang menjadi asa meskipun cara yang digunakan untuk mencapai itu adalah dengan menggunakan intimidasi, manipulasi, dan represi terhap pihak yang disubalternasi. Hubungan tersebut dapat dilihat dalam data kutipan berikut ini.
"Syaratnya...," kalimat Basudewo terhenti, tetapi tatapannya pada Ranting tetap melekat tak berjeda. Begitu tenang tatapan itu, tapi alangkah tak tergoyahkan. Andai divisualisasikan, barangkali akan berupa adegan ular kobra yang tegak melebarkan tudung lehernya dan bersiap menelan anak ayam yang terduduk satu langkah di depannya.

"Kamu sudah menjadi perawan yang ayu..." (Kuncoro, 2009, hlm. $49-50)$.

Kutipan data tersebut menunjukkan represi pihak kuat terhadap pihak yang lemah. Cobra digambarkan sebagai pihak yang lebih kuat dibandingkan dengan anak ayam. Anak ayam merepresentasikan sesuatau yang sangat lemah dan tidak memiliki cukup daya untuk melawan seekor kobra. Sama dengan kondisi Ranting. Ranting tidak memiliki nilai tawar untuk menolak keinginan Basudewo. Ranting hanya bisa pasrah dan menuruti keinginan Basudewo agar nyawa ibunya dapat diselamatkan. Kekayaan Basudewo memosisikan Basudewo laksana kobra yang melebarkan tudung lehernya dan siap untuk memangsa Ranting. Sebuah representasi relasi kuasa. Basudewo sebagai sosok yang 
ordinat dan Ranting mewakili yang subordinat.

Interpretasi terhadap novel GP dapat dinyatakan bahwa hubungan kekuasaan antara laki-laki dan perempuan yang terdapat dalam novel tersebut merupakan hubungan kekuasaan yang bersifat politik. Politik tidak ditentukan oleh siapa yang memenangkan pertandingan, tetapi ditentukan oleh siapa yang membuat peraturan permainan. Dalam hal ini Basudewo yang membuat peraturan. Basudewo mau membantu, asalkan Ranting mau dijadikan sebagai istri ketiga. Jika Ranting menolak keinginan Basudewo, maka nyawa ibunya yang jadi taruhan. Itulah peraturan yang dimainkan oleh Basudewo untuk dapat menguasi tubuh, keperawanan, dan kecantikan Ranting.

Hubungan antara Ranting dan Basudewo di akhir cerita menjadi terbalik setelah Ranting membuat peraturan permainan sendiri atas kehidupannya. Dia membuat aturan main dengan memutuskan bahwa dia menjual dirinya kepada Basudewo dengan harga dua ratus lima puluh ribu dalam setiap persenggamaan dengan Basudewo. Ranting memposisikan dirinya sebagai istri sekaligus pelacur bagi Basudewo. Sebagai istri karena mereka telah terikat dengan perkawinan. Sebagai pelacur karena Ranting mematok harga dua ratus lima puluh ribu setiap kali Basudewo menyengamainya. Setelah seratus kali dia melayani Basudewo, maka biaya dokter yang dikeluarkan oleh Basudewo akan dianggap lunas.

"Akan kuhitung setiap kali dia
datang dan melakukannya. Akan
kucatat tanggal kedatangannya,
sebagai bukti dan data pendukung
pada akhir perhitungan nanti."
(Kuncoro, 2009:99).

Aturan permainan yang ditetapkan oleh Ranting adalah sebuah bentuk upaya untuk melepaskan diri dari transaksi seksual yang menimpa dirinya akibat kemiskinan yang membelenggu tokoh ini. Hal tersebut merupakan suatu usaha untuk menguatkan dan mengokohkan jiwanya dalam mengembalikan harga dirinya sebagai sosok perempuan sehingga ia akan memiliki tubuhnya secara utuh. Dapat diintepretasikan bahwa Ranting ingin kembali menjadi dirinya sendiri, bukan menjadi liyan.

Hubungan kekuasaan yang terjadi antara tokoh perempuan dan tokoh laki-laki adalah hubugan kekuasaan yang simetris. Hal tersebut menunjukkan bahwa perempuan sebenrnya memiliki kekuasaan atas dirinya sendiri. Meskipun apa yang dipilih oleh Ranting adalah sesuatu yang jauh dari kata normal, namun hal tersebut menunjukkan 
bahwa tidak ada dikotomi kekuasaan antara laki-laki dan perempuan. Meskipun mitos tersebut masih mengakar sangat kuat dalam kehidupan masyarakat. Melalui tokoh Basudewo, pengarang ingin mengugurkan mitos tersebut. Hal ini dapat dilihat dari pernyataan Basudewo berikut ini.

"Bahwa selama ini kau merasa kuperkosa. Tindakan pemerkosaan bisa dituntut dengan UU Kekerasan dalam Rumah Tangga, entah pasal berapa. Aku melakukannya 99 kali, berulang-ulang. Jadi, hukuman apa yang akan divoniskan kepadaku? Tapi, kau menanggungnya sendirian, tanpa punya kemampuan untuk menuntutku karena kau terjebak dalam ikatan perkawinan denganku, pemerkosamu. Itu yang tak akan terbayar olehku, berapa pun harta yang kuberikan kepadamu sebagai penukarnya.”(Kuncoro, 2009:117).

Kutipan tersebut menyiratkan bahwa tidak ada lagi pihak yang mendominasi dan pihak yang didominasi. Tidak ada lagi hubungan kekuasaan yang vertikal antara laki-laki dengan perempuan. Sekilas hubungan kekuasaan yang ada adalah hubungan kekuasaan yang horisontal atau simetris. Akan tetapi, hubungan tersebut masih bersifat simetris karena Ranting tidak pernah menawarkan 'aturan permainan barunya' kepada Basudewo secara langsung. Ranting menetapkan 'aturan' itu secara sepihak tanpa sepengetahuan Basudewo. Hal tersebut adalah sebuah bentuk upaya perempuan untuk mendapatkan kebebasan dan persamaan hak kaum perempuan.

Hubugan kekuasaan antara Ranting dan Basudewo menunjukkan bahwa uang mampu membuat seseorang menjadi pihak yang tersubalternasi dan pihak yang mensubalternasi. Seseorang yang memiliki kekayaan melimpah biasanya akan menduduki pihak yang mensubalternasi. Sebaliknya, orang yang tidak memiliki kekayaan akan menjadi pihak yang tersubalternasi dan suara serta aspirasinya tidak akan pernah didengarkan. Pihak yang tersubalternasi tidak memiliki kekuatan untuk menyuarakan keinginan dan aspirasinya. Akan tetapi, di sisi lain perempuan juga dapat menggunakan daya tarik seksualnya untuk mendapatkan uang sehingga akan terjadi proses tawar menawar untuk membebaskan diri dari cengkraman sistem tersebut.

\section{Hubungan Kekuasaan Gendhing dengan Rentenir dan Indragiri}

Hubungan kekuasaan antara Gendhing dengan rentenir dan Indragiri 
melambangkan hubungan kekuasaan antara penguasa dan rakyat jelata. Gendhing merupakan tokoh protagonis yang merepresentasikan perempuan Jawa dari golongan bawah. Rentenir dan Indragiri adalah tokoh laki-laki yang merepresentasikan kekuasaan dan subyek alternasi.

Pasangan suami istri itu terdiam. Tidak ada sepatah kata yang tersisa, yang sekiranya memadai sebagai jawaban. Sama seperti halnya tidak ada yang tersisa di dalam rumah itu, yang memadai sebagai alat pembayar utang.

"Atau Gending saja kubawa?" Bandar itu mengajukan alternatif.

"Hanya dia hartamu yang bisa kupakai sebagai pelunasan, mau bagaimana lagi?"

"Bawa aku saja," Ibu menawarkan diri dengan ketakutan yang tak tersamarkan.

"Untuk apa kubawa dirimu? Kau sudah tua, kujual tak akan laku, kupakai sendiri juga tak mungkin, aku sungguh tak berselera" (Kuncoro, 2009, hlm. 183).
"Justru karena itu aku menginginkanmu."

"Tapi, padamu yang kuperlukan adalah uangmu. Maka, akan kuberikan apa yang kau mau. Perawanku. Dan, itu bukan sesuatu yang gratis, bahkan tidak murah."

"Berapa?"

"Seratus juta, bayar di muka dan kau harus menggunakan pengaman karena aku tidak mau menerima cairanmu!"

Indragiri tercenggang. Bukan karena angka yang diucapkan Gending. Berapa pun angka itu, bukanlah sesuatu yang sangat berarti baginya. Kemampuan finansial telah menempatkannya pada suatu posisi bahwa harga bukanlah masalah. Dia telah sampai pada suatu posisi yang disebutnya sebagai financial freedom. Merdeka dalam hal keuangan, tidak terhambat oleh batasan harga ketika menginginkan sesuatu (Kuncoro, 2009, hlm. 204).

Kedua kutipan tersebut menunjukan bahwa Gendhing berada di bawah kekuasaan Rentenir dan Indragiri. Hal tersebut dapat diintepretasikan bahwa hubungan kekuasaan yang terjadi antara laki-laki dan perempuan 
bersifat vertikal atau asimetris. Ada golongan atau pihak yang berada di posisi atas dan ada pihak yang berada di posisi bawah. Dalam hubungannya dengan Rentenir, status Gendhing adalah sebagai alat pelunasan hutang jika kedua orang tuanya tidak mampu membayar hutang-hutang mereka. Dalam keadaan seperti tersebut, Gendhing ditempatkan dalam posisi objek atau orang yang terepresi. Gendhing tidak dapat melakukan apa-apa jika dalam waktu yang telah ditentukan ternyata dia tidak mampu membayar hutang-hutang orang tuanya selain memasrahkan diri kepada sang rentenir karena dijadikan sebagai alat pembayaran. Dalam hal ini Gendhing tidak memiliki kebebasan untuk menentukan pilihan. Pilihan yang ada hanya satu. Gendhing dijadikan sebagai alat pembayaran hutang dan dia harus melakukan segala keinginan rentenir. Hal tersebut disebabkan karena dia telah menjadi hak dan milik sang rentenir.

Hubungan kekuasaan asimetris terjadi antara sang rentenir yang memiliki kepentingan, uang yang dipinjam oleh Ibu Gending kembali, dengan mereka yang termarjinal, Ibu Gending yang meminjam uang. Karena kekuasaan yang dimilikinyalah akhirnya sang rentenir dapat memanipulasi Ibu Gending untuk rela menyerahkan anaknya sebagai alat pembayaran hutang. Ibu Gending tidak memiliki akses kepada kekuasaan hegemoni yang pada akhirnya ia mengambil keputusan agar dirinyalah yang dijadikan sebagai alat pembayaran hutang.

"Untuk apa kubawa dirimu? Kau sudah tua, kujual tak akan laku, kupakai sendiri juga tak mungkin, aku sungguh tak berselera" (Kuncoro, 2009, hlm. 183).

Kutipan tersebut menunjukkan muncul hubungan kekuasaan yang asimetris antara laki-laki dan perempuan. Hubungan ibu Gendhing dengan rentenir menunjukkan adanya hegemoni kekuasaan. Pihak yang memiliki kekuasaannya akan mampu menekan dan mengintimidasi pihak yang diintmidasi sampai keinginan dan hasratnya terpeuhi. Hubungan tersebut mengakibatkan perempuan selalu menempati posisi menjadi objek yang dieksploitasin secara kultural. Perempuan tidak memiliki kemampuan dan keberanian untuk menolak keinginan lakilaki. Perempuan tidak memiliki sesuatu yang dapat dijadikan sebagai "bahan tawar" pada saat laki-laki melakukan subalternasi terhadap dirinya.

Kutipan tersebut juga merepresentasikan perempuan menjadi pihak yang tersubordinasi secara seksual. Sejak lahir, kanak-kanak, remaja, dewas, dan tua perempuan tidak akan pernah menjadi 
dirinya sendiri. Sejak lahir perempuan sudah menjadi milik konstruksi budaya yang dibentuk oleh kaum patriarki.

Ketidakberdayaan

Gendhing mengumpulkan uang puluhan juta dalam waktu sebulan untuk membayar hutanghutangnya menyebabkan ia mengambil suatu keputusan. Keputusan tersebut adalah menjual keperawanannya kepada Indragiri. Hubungan kekuasaan yang terjadi antara Indragiri dengan Gendhing juga bersifat asimetris. Indragiri sebagai pihak yang di atas dan Gendhing sebagai pihak yang di bawah. Indragiri sebagai pihak yang dibutuhkan dan memiliki nilai tawar tinggi dan Gendhing menempati posisi yang membutuhkan tanpa memiliki nilai tawar untuk melakukan negoisasi.

Sebuah pilihan yang sangat dilematis bagi Gendhing. Tidak dapat membayar hutang tubuhnya akan dinikmati oleh sang rentenir. Dapat membayar hutang, tetapi dia harus menyerahkan keperawanannya kepada Indragiri dalam suatu proses kontrak persenggamaan. Hal tersebut menunjukkan bahwa di dalam masyarakat telah tumbuh dan berkembang sebuah sistem yang bernama deskriminasi sistemik. Karena suatu keadaan tertentu, adat, norma, ataupun struktur suatu komunitas sosial, hal yang sebenarnya deskriminatif menjadi hal yang biasa dan tidak deskriminatif. Dalam

kehidupan masyarakat sudah bukan persoalan yang baru tatkala perempuan dijadikan sebagai objek seksual. Perempuan tidak memiliki kekuasaan atas seksual dirinya karena ketidakberdayaan dalam menghadapai persoalan kehidupan. Keadaan seperti inilah yang pada akhirnya memunculkan hubungan yang asimetris antara laki-laki dengan perempuan. Gendhing menjadi pihak yang subordinat dan Rentenir serta Indragiri menjadi pihak yang superordinat.

Hubungan berubah menjadi asimetris pada saat Gendhing menyadari bahwa berapa pun jumlah uang yang ditawarkan untuk mendapatkan keperawanannya tidak akan dapat mengebalikan harga dirinya sebagai sosok yang dihargai. Pembatalan Gendhing terhadap kontrak seksualnya dengan Indragiri membuatnya ia memiliki nilai tawar atas dirinya. Posisi menjadi berubah pada saat Indragiri menaikkan tawarannya menjadi dua kali lipat, yaitu 200 juta. Gendhing tidak lagi menempati posisi yang membutuhan, melainkan menempati posisi yang dibutuhkan. Hal tersebut dapat diliat dalam kutpan berikut ini

"Dua ratus juta?" 
"Tidak berapa pun," kata Gendhing dingin, mengendalikan kemarahan diri. "Tidak akan pernah ada angka untuk hargaku. Segala angka tidak akan pernah cukup untuk menjadikan nilai tukar yang layak bagi seseorang, aku atau siapa pun."

"Ya, menyerah padamu artinya menyerah pada nasib, tidak akan kulakukan. Aku akan melawan.” (Kuncoro, 2009:209—210).

"Sekali pun kau akan mengalir pada sugai buntu?"

"Bagian dari resiko, akan kuhadapi."

"Kau telah melakukannya. Kau memiliki keberanian menjalani resiko. Pilihanmu membtalan transasksi semalam itu membuatmu tetap miskin, menanggung utang yang diambil alih Cik Ming sehingga menjadikanmu sbagai pekerja tanpa gaji sekian tahun. Di atas semua itu kau pertahankan wibawamu sebagai anak, sebagai perempuan" Kata Tawangsri lugas, selurus tatap matanya.” (Kuncoro, 2009:366)
Sebuah representasi bahwa sebenarnya perempuan mampu menempati posisi yang sama dengan laki-laki jika perempuan berani untuk melakukan perlawanan dan keluar dari "zona nyaman" yang laki-laki berikan serta menanggung semua akibatnya. Untuk mempertahankan harkat dan martabatnya sebagai sosok perempuan, Gendhing berani membatalkan kontrak seksualnya. Dia berani menanggung resikonya untuk hidup dalam kungkungan kemiskinan dan bekerja sekian tahun tanpa digaji untuk mengangsur hutangnya kepada Cik Ming. Sebuah bentuk perlawanan terhadap konstruksi budaya yang akan menempatkan perempuan tidak lagi sebagai objek, melainkan sebagai subjek. Situasi tersebut akan membawa dampak terhadap hubugan kekuasaan antara laki-laki dan perempuan. Jika perempuan berani melakukan seperti apa yang dilakukan oleh Gendhing, hubungan kekuasaan antara lakilaki dengan perempuan tidak asimetris, melainkan simetris.Tidakakan muncul pihak yang menjadi penguasa dan pihak yag dikuasai.

\section{Hubungan Kekuasaan Tawangsri dengan} Jenggala

Hubungan antara Tawangsri dengan Jenggala berbeda dengan hubungan kekuasaan antara Gendhing dengan Indragiri, 
dan Ranting dengan Basudewo. Hubungan kekuasaan yang terjadi antara Tawangsri dengan Jenggala bersifat ambivelen. Hal tersebut disebabkan hubungan keduanya memiliki karakter atau dapat dikategorikan ke dalam hubunga simetris yang suatu saat bisa berubah menjadi hubungan yang asimetris. Jika Ranting berhubungan dengan Basudewo karena terpaksa, begitu juga Gendhing berhubungan dengan rentenir dan Indragiri juga karena keadaan yang memkasa, Kedua tokoh ini, Tawangsri dan Jenggala menjalin hubungan bukan karena rasa keterpaksaan, melainkan karena keduanya memiliki rasa saling menyukai. Hal inilah yang menyebabkan hubungan kekuasaan tokoh ini dapat dikategorikan ke dalam hubungan yang simetris.

Tawangsri menaruh perhatian pada seorang pria yang sedang bermain di taman bersama anaknya. Pria itu adalah Jenggala, orang tua tunggal yang mengasuh anaknya sendirian tanpa didampingi oleh seorang istri. Istri Jenggala meninggal pada saat melahirkan anaknya. Jenggala mencoba untuk menutup hatinya dari perempuan hingga pertemuannya dengan Tawangsri yang sangat menrik perhatiannya. Perkenalan di taman menghantarkan sebuah perasaan aneh yang menghampiri keduanya. Rasa itu semakin besar tatkala Tawangsri mengetahui pandangan Jenggala tentang perempuan yang sangat memuliakan dan menghormati perempuan. Hal tersebut dapat dilihat dalam kutipan berikut ini,

"Kadang-kadang dunia memang terasa sangat patriarkat. Ada keterbelahan yang tajam pada kedudukan perempuan saat ini. Sebagian perempuan menempati posisi baik di ruang publik, sementara banyak perempuan lainnya, menjalani hidup tanpa pilihan lain selain menjadi ibu dan sarana rekreasi seksual para suami." (Kuncoro, 2009:255).

Hal yang menarik untuk dikaji adalah sikap Tawangsri yang sangat proaktif. Sifat proaktif tersebut dapat diintepretasikan ketika ia menentukaan pilihan kepada siapa keperawanan yang ia miliki akan ia serahkan. Apa yang dilakukan oleh Tawangsri adalah menunjukkan adanya pergeseran posisi. Perempuan yang biasanya menempati posisi dipilih berubah menjadi perempuan yang memiliki posisi untuk memilih. Ada semacam pendekonstruksian terhadap tatanan sosial di masyarakat patriarki yang menyatakan bahwa lanang menang milih diubah menjadi wedok menang milih. Muncul kesetaraan gender di ranah publik. Hal tersebut menunjukkan bahwa lahirnya 
suatu kondisi karena sesorang memiliki keinginan dan kekuasaan yang kuat atas dirinya. Hal tersebut dapat dilihat dalam kutipan berikut ini.

"Akan kupergunakan hak pilihku untuk menentukan siapa lakilaki pertamaku. Sama seperti seorang laki-laki memilih perempuan pertamanya. Tidak ada keharusan bagiku untuk tetap menjadi perawan demi sebuah pernikahan. Menjadi tetap perawan atau tidak adalah suatu pilihan dan aku hanya akan melakukannya dengan seseorang yang kuinginkan, dengan atau tanpa pernikahan.” (hal 274).

Sikap hidup Tawangsri adalah sebagai sebuah pemberontakan tatanan sosial yang ada di dalam komunitas sosial. Keinginan untuk mencapai kehidupan yang lebih baik, keluar dari menjadi liyan karena apa yang ada dalam tubuhnya adalah miliknya, dirinya adalah miliknya, bukan milik orang lain.

Hubungan Kekuasaan Zhang Mey dengan Tenggar

Hubungan kekuasaan yang terjadi antara Zhang Mey dan Tenggar memiliki tipe yang sama dengan hubungan Tawangsri dan
Jenggala. Di satu sisi hubungan tersebut bersifat simetris, di sisi lain hubungan itu bersifat asimetris. Hubungan bersifat asimetris tatkala Zhang Mey memaksakan kehendaknya kepada Tenggar untuk mengambil keperawananya sebelum ia menjalankan tradisi keluarganya yaitu menikah dengan laki-laki pilihan keluarganya, menjalankan kewajiban istri untuk melayani suami, dan mempersembahkan keperawanannya kepada sang suami. Hal tesebut dapat dilihat dalam kutipan berikut ini

"Itu tidak akan kau dapatkan karena aku akan melaksanakan kewajibanku, menjalani tradisi atas nama kehormatan keluarga, menjadi pengantin yang perawan bagi seorang laki-laki yang terpilih sebagai suamiku pada masa nanti." (Kuncoro, 2009:351).

Zhang Mey memiliki pemikiran yang sama dengan Tawangsri bahwa apa yang ada dalam dirinya adalah seutuhnya miliknya. Zhang Mey ingin memberikan keperawanannya kepada orang ia pilih karena kemauannya sendiri bukan karena keinginan orang lain. Zhang Mey ingin menjadi tuan atas tubuhnya dan terbebas dari belenggu tradisi yang menempatkan perempuan di 
posisi yag subordinat. Sebuah perjuangan untuk menjadi diri sendiri seutuhnya. Pilihan hidup yang menjungkirbalikan tradisi yang ada. Tidak selamanya perempuan pasif dan selalu menjadi pihak yang dipilih. Perempuan juga mampu untuk aktif dan memilih jika dia memiliki kekuasaan yang penuh atas dirinya.

\section{PENUTUP}

Hubungan kekuasaan antara laki-laki dan perempuan yang terdapat dalam novel Garis Perempuan karya Sanie B. Kuncoro adalah hubungan yang asimetris. Laki-laki menduduki posisi yang ordinat dan perempuan menduduki posisi yang subordinat. Perempuan menjadi pihak yang kedudukannya di bawah laki-laki. Hal tersebut disebabkan konstruksi budaya yang dibuat oleh kaum patriarki menganggap perempuan sebagai lapis kedua. Konstruksi tersebut mengakibatkan perempuan menjadi liyan.

Konstruksi budaya yang dibentuk oleh kaum patriarki sebenarnya tidak bersifat permanen atau statis. Konstruksi tersebut masih dapat diubah jika perempuan memilik keberanian untuk mengubahnya. Melalui keempat tokoh yang terdapat dalam karnyanya, Sanie B. Kuncoro menawarkan suatu alernatif subjektif tentang konstruksi tersebut. Setelah melakukan perlawanan, ternyata huungan kekuasaan yang bersifat asimetris dapat berubah mejadi simetris. Perempuan tidak lagi menjadi liyan. 


\section{DAFTAR PUSTAKA}

Abrams, M.H. 1981. A Glossary of Literary Term. New York. Holt Rinehart and Winston.

Al-Ali, Nadje Sadig. 1994. Gender Writing/Writing Gender-The Representation of Woman in a Selection of Modem Egyptian Literature. The American University in Cairo Press.

Departemen Pendidikan Nasional. 2008. Kamus Besar Bahasa Indonesia Pusat Bahasa. Ed. Keempat. Jakarta: Gramedia Pustaka Utama.

Faruk. 1999. Pengantar Sosiologi Sastra. Jogyakarta: Pustaka Pelajar.

Fakih, Mansour. 1997. Analisis Gender dan Transformasi Sosial. Yogyakarta: Pustaka Pelajar.

Figes, Eva. 1986. Patriarchal Attitudes. London. Macmillan Education.

Forster, E.M. 1977. Aspects of The Novel. Penguin Book.

Jones, Pip. 2010. Pengantar Teori-Teori Sosial.Jakarta: Yayasan Pustaka Obor Indonesia.

Michael Sheehan. 1996. The Balance of Power: History \& Theory. London: Routledge.

Nurgiyantoro, Burhan. 2009. Teori Pengkajian Fiksi. Yogyakarta: Gajahmada University Press.
Sulistya, Prima dkk. 2011. Karnaval Caci Maki. Yogyakarta : Ekspresi Buku.

Tierney, Helen. ed. 1991. Women's Studies Encyclopedia. New York: Peter Bedrick Books.

Wellek dan Warren. 1995. Teori Kesusastraan. Jakarta: Gramedia. 